\title{
ANALISIS PENERAPAN BASIS AKRUAL ATAS STANDAR AKUNTANSI PEMERINTAH NO 71 DAN DAMPAKNYA PADA PENYAJIAN LAPORAN KEUANGAN (STUDI KASUS PADA SATUAN KERJA PERANGKAT DAERAH KECAMATAN CIPUTAT TIMUR)
}

\author{
Yunita Kurnia Shanti \\ Universitas Pamulang, Tangerang Selatan
}

Kurniay25@gmail.com

\begin{abstract}
All government entities using funds from national and regional budgets must preparing financial reports referring to government accounting standard will be regulated in goverment regulate number 71 in 2010 and start begin on 2015. The regional goverment financial reports required to be properly according to applicable regulation. Financial reports regional was a responsibility and performance picture in an accounting periods. This study aimed to analyze accrual base application on goverment accounting standart and the impact of financial statement present in unit kecamatan ciputat east. Methods used is descriptive qualitative, through observation, interview, analysis and make inferences. The research results showed the application of the base accrued in the presentation of the fifth financial reports are in principle in accordance with sap regulation no 71 years 2010. Explanation of operational reports and the equity changes report were not discloused in an adequate on CALK. The impact caused by the accounting system based akrual (SIMRAL) that this report financial more than easier, quick and integrated, and can tell about information budget expended and can be monitored directly by the management to decision maker.
\end{abstract}

Keywords : Accrual Base, Financial Statement, Government Accounting Standard, Accounting System

\begin{abstract}
Abstrak
Semua entitas pemerintah yang menggunakan dana yang berasal dari Anggaran Pendapatan Belanja Negara (APBN) dan Anggaran Pendapatan Belanja Daerah (APBD) wajib menyusun laporan keuangan dengan mengacu pada Standar Akuntansi Pemerintah berbasis akrual sesuai Peraturan Pemerintah No. 71 tahun 2010 pada awal 2015. Laporan keuangan pemerintah daerah merupakan bentuk pertanggungjawaban penggunaan Anggaran dan gambaran kinerja pemerintah daerah dalam satu periode akuntansi. Penelitian ini menganalisis penerapan basis akrual atas SAP No 71 tahun 2010 dan mengetahui dampak penyaJIAn laporan keuangan pada SKPD Kecamatan Ciputat Timur. Metode yang digunakan adalah
\end{abstract}


deskriptif kualitatif melalui pengamatan, wawancara, analisis dan membuat kesimpulan. Hasil penelitian menunjukkan penerapan basis akrual pada penyajian kelima laporan keuangan telah sesuai dengan SAP 71 tahun 2010. Untuk pengungkapan laporan operasional dan laporan perubahan ekuitas belum dijelaskan secara memadai dalam CALK. Dampak yang ditimbulkan dengan adanya sistem akuntansi berbasis akrual (SIMRAL) bahwa penyusunan laporan keuangan lebih mudah, cepat, dan terintegrasi, serta dapat memberikan informasi realisasi anggaran dan dipantau secara langsung oleh manajemen guna membantu pengambilan keputusan.

Kata Kunci : basis akrual, laporan keuangan, standar akuntansi pemerintah, sistem akuntansi

\section{PENDAHULUAN}

Dalam lingkungan keuangan pemerintahan, pihak eksekutif menyusun anggaran dan menyampaikan kepada legislatif untuk mendapat persetujuan. Untuk mewujudkan transparansi dan tata kelola yang baik (good governance) dalam menggunakan anggaran tersebut pihak eksekutif bertanggung jawab kepada rakyat melalui legislatif. Menurut Bastian Indra (2014 : 8) Kementerian dalam organisasi sektor publik memiliki wewenang dan tanggung jawab utama termasuk menyediakan laporan keuangan organisasi tersebut. Semua entitas pemerintah yang menggunakan dana yang berasal dari Anggaran Pendapatan Belanja Negara (APBN) dan Anggaran Pendapatan Belanja Daerah (APBD) wajib menyusun laporan keuangan berdasarkan standar akuntansi pemerintahan yang berlaku sebagai bentuk pertanggungjawaban seperti yang tertuang dalam Peraturan Pemerintah No 8 Tahun 2006 tentang pelaporan keuangan dan kinerja Instansi pemerintah. Organisasi pada sektor publik atau pemerintahan dapat berupa kementerian, pemerintah daerah, badan usaha milik negara/ daerah, badan layanan umum dan lainnya. Basis akuntansi yang berlaku di Indonesia meliputi basis kas dan basis akrual yang mana basis kas adalah dasar pencatatan akutansi yang dilakukan pada saat kas diterima atau kas dibayar, sedangkan basis akrual adalah dasar pencatatan akuntansi yang dilakukan pada saat transaksi terjadi sudah dapat diakui.

Basis akuntansi pada sektor publik atau sektor pemerintahan sampai dengan akhir tahun 2014 menggunakan dasar pencatatan akuntansi kas menuju akrual atau yang disebut CTA (cash toward accrual). Mulai Januari 2015 semua entitas diwajibkan menerapkan basis akrual sebagai dasar pencatatan laporan keuangan dengan mengacu Standar Akuntansi Pemerintah berbasis akrual sesuai Peraturan Pemerintah No. 71 tahun 2010 dengan maksud memberikan manfaat lebih bagi para pemangku kepentingan. Ini berarti terdapat perubahan jumlah laporan keuangan yang disajikan dari sebelumnya berjumlah 4 (empat) laporan keuangan yaitu Laporan Realisasi Anggaran, Laporan Posisi Keuangan, Laporan Arus Kas dan Catatan Atas Laporan Keuangan mulai awal Tahun 2015 bertambah 
3 laporan yaitu laporan Operasioanl, Laporan perubahan ekuitas, dan laporan sado anggaran kurang/ lebih. Dalam entitas pemerintah pusat kewajiban penyusunan laporan keuangan berbasis akrual sebanyak 5 (lima) laporan keuangan tidak termasuk laporan arus kas dan laporan saldo anggaran kurang/ lebih yang mana menjadi kewajiban kementerian keuangan selaku Bendahara Umum Negara (BUN).

Fenomena yang berbeda dengan pemerintah daerah yang mana penyusunan laporan keuangan bagi entitas pemerintah daerah provinsi/ kabupaten/ kota selain berdasarkan Standar Akuntansi Pemerintah dalam PP No. 71 tahun 2010 juga mengacu pedoman kebijakan akuntansi pemerintah daerah yang diatur dalam Peraturan Menteri DalamgNegeri No. 64 Tahun 2013 tentang penerapan standar akuntansi pemerintah berbasis akrual pada pemerintah daerah. Masing-masing Kepala daerah mempunyai kewenangan mengatur dan menyusun kebijakan akuntansi yang berlaku di daerahnya dengan mengacu pada PP No 71 Tahun 2010 dan Permendagri No 64 Tahun 2013. Salah satunya kebijakan akuntansi yang berlaku pada pemerintah daerah kota Tangerang Selatan yaitu diterbitkannya Peraturan Walikota Tangerang Selatan No 10 Tahun 2014 mengatur tentang kebijakan akuntansi pemerintah daerah dan Peraturan Walikota Tangerang selatan No. 24 Tahun 2013 tentang sistem akuntansi pemerintah daerah yang digunakan untuk mendukung pencatatan dan penyaJIAn laporan keuangan daerah.

Peraturan tersebut menjadi dasar untuk dilaksanakan oleh semua perangkat daerah dalam menyusun laporan keuangan yang dimulai dari tingkat Satuan kerja perangkat daerah (SKPD). Dalam struktur organisasi Kota Tangerang Selatan mempunyai 36 SKPD yaitu terdiri dari 29 dinas dan 7 kecamatan. Menurut Tunggal (2016:16\} struktur organisasi suatu entitas dapat menyediakan kerangka kerja terkait kegiatan entitas untuk mencapai tujuan entitas yang telah direncanakan dan entitas dapat mengembangkan struktur organisasi sesuai kebutuhannya. Kota Tangerang Selatan semakin berkembang selama 9 tahun tentunya banyak hal terkait peraturan dan kebijakan akuntansi yang dibuat. Hal ini tentunya untuk mendukung tercapainya akuntabilitas dan transparansi publik bahwa melihat laporan keuangan yang disajikan layak mendapatkan opini terbaik yaitu Wajar Tanpa Pengecualian.

Beberapa penelitian kualitatif terdahulu seperti dijelaskan (Yani Olga : 2014) penerapan sap 71 tahun 2010 pada SKPD dinas pendapatan dan pengelolaan aset daerah. Selanjutnya penelitian (Miftahul Jannah : 2015) tentang dampak kebijakan akuntansi pemerintah daerah atas PP No 71 Tahun 2010 dalam rangka pemberian opini laporan keuangan pada dinas pendapatan dan pengelolaan keuangan daerah. Dan Penelitian (Paula Ezra : 2016) tentang penyaJIAn laporan keuangan daerah sesuai PP No. 71 Tahun 2010 pada dinas pendapatan daerah. Masih minimnya penelitian kualitatif tentang penerapan standar akuntansi pemerintah pada pemerintah daerah mendorong peneliti tertarik untuk melakukan penelitian terhadap kesesuaian penerapan SAP 71 Tahun 2010. Berdasarkan teori, fenomena dan penelitian terdahulu tersebut peneliti ingin mengambil judul analisis penerapan basis akrual atas SAP 71 Tahun 2010 dan mengetahui dampak yang terjadi pada penyaJIAn laporan keuangan pada SKPD kecamatan ciputat timur Kota Tangerang Selatan. 


\subsection{Rumusan Masalah}

1) Bagaimana kesesuaian penerapan basis akrual secara penuh yang mengacu SAP 71 dan Permendagri 64 Tahun 2013 pada SKPD kecamatan ciputat timur dalam penyaJIAn laporan keuangan ?

2) Bagaimana dampak yang ditimbulkan pada penyaJIAn laporan keuangan SKPD ?

\subsection{Tujuan penelitian}

Tujuan dalam penelitian ini adalah sebagai berikut :

1) Untuk menganalisis kesesuaian penerapan SAP 71 dalam penyusunan laoran keuangan daerah pada SKPD Kecamatan ciputat timur

2) Untuk menganalisis dampak yang ditimbulkan pada penyaJIAn laporan keuangan SKPD

\section{TINJAUAN PUSTAKA}

\subsection{Akuntansi Pemerintahan}

Sujarweni (2015:18) menjelaskan akuntansi pemerintahan adalah akuntansi yang bersangkutan dengan bidang keuangan negara dari anggaran sampai pelaksanaan dan pelaporan termasuk pengaruh yang ditimbulkan. Akuntansi pemerintah termasuk juga lembaga-lembaga non profit mengkhususkan pada masalah dan pelaporan transaksi dari unit-unit pemerintah dan organisasi non profit lainnya. Fungsi akuntansi pemerintah adalah menyediakan laporan akuntansi yang bermanfaat mengenai aspek kepengurusan administrasi pemerintah, serta membantu manajemen dalam melaksanakan pengawasan atas pelaksanaan anggaran sesuai dengan ketentuan undang-undang yang berlaku (Sadeli, 2015 :6). Menurut hariadi, restianto dan bawono (2010:122) dalam kerangka konseptual pemerintah dijelaskan mengenai tujuan pelaporan keuangan daerah adalah sebagai berikut :

a. Menyediakan informasi tentang sumber, alokasi dan penggunaan sumber daya keuangan

b. Menyediakan informasi mengenai kecukupan penerimaan periode berjalan untuk membiayai seluruh pengeluaran

c. Menyediakan informasi mengenai jumlah sumber daya ekonomi yang digunakan dalam kegiatan entitas pelaporan serta hasil-hasil yang telah dicapai

d. Menyediakan informasi mengenai bagaimana entitas pelaporan mendanai seluruh kegiatannya dan kecukupan kasnya

e. Menyediakan informasi mengenai posisi keuangan dan kondisi entitas pelaporan berkaitan dengan sumber-sumber penerimaanya baik jangka pendek maupun jangka panjang, termasuk yang berasal dari pungtan pajak dan pinjaman. 
f. Menyediakan informasi mengenai perubahan posisi keuangan entitas pelaporan, apakah mengalami kenaikan atau penurunan, sebagai akibat kegaitan yang dialkukan selama periode pelaporan.

\subsection{SAP Kas menuju Akrual}

Laporan keuangan disusun untuk memberikan informasi mengenai posisi keuangan dan semua transaksi yang terjadi selama satu periode pada entitas pelaporan yaitu pemerintah pusat, pemerintah daerah provinsi/kota/ kabupaten dan lembaga pemerintah sesuai standar akuntansi pemerintah (SAP) yang ditetapkan. Menurut SAP 71 Tahun 2010 yang sebelumya tertuang dalam PP No 24 Tahun 2005 bahwa Sistem akuntansi pemerintah merupakan prinsip-prinsip akuntansi yang diterapkan dalam menyusun dan menyajikan laporan keuangan pemerintah. Dalam hal pengakuan dan pengukuran pada masing-masing pos yang terdapat dalam laporan keuangan disebut basis akuntansi. Penerapan standar akuntansi pemerintahan dibedakan menjadi dua yaitu standar akuntansi pemerintah berbasis kas menuju akrual dan standar akuntansi pemerintah berbasis akrual.

SAP berbasis kas menuju akrual adalah Standar akuntansi pemerintah yang mengakui pendapatan, belanja, transfer dan pembiayaan berbasis kas, serta mengakui aset, kewajiban dan ekuitas dana berbasis akrual. SAP berbasis kas menuju akrual diterapkan dalam masa transisi bagi entitas yang belum siap menerapkan SAP berbasis akrual pada tahun 2015. Laporan keuangan yang dihasilkan meliputi laporan realisasi anggaran, neraca, laporan arus kas dan catatan atas laporan keuangan. Dalam penyusunan dan penyaJIAn laporan keuangan dibagi dalam dua entitas yaitu entitas pelaporan dan entitas akuntansi. Untuk entitas akuntansi yaitu entitas yang menyajikan laporan keuangan satuan kerja untuk disampailkan ke entitas pelaporan menyusun neraca, laporan realisasi anggaran dan catatan atas laporan keuangan. Dan untuk entitas pelaporan yaitu entitas yang menyusun laporan keuangan pemerintah pusat maupun pemerintah daerah secara konsolidasi maka ditambahkan laporan arus kas dari ketiga laporan keuangan tersebut.

\subsection{SAP Berbasis Akrual}

Seperti telah dijelaskan sebelumnya mengenai definisi SAP dan kapan penerapan basis akuntansi dalam SAP. Bahwa basis akrual adalah basis akuntansi yang mengakui transaksi pada saat terjadi bukan pada saat kas diterima ataupun dibayarkan. Untuk SAP berbasi akrual merupakan SAP yang mengakui pendapatan-LO, beban, aset, kewajiban dan ekuitas dalam pelaporan finansial berbasis akrual, serta mengakui pendapatan, belanja dan pembiayaan dalam pelaporan pelaksanaan anggaran berdasarkan basis yang ditetapkan dalam APBN/ APBD. Laporan keuangan yang dihasilkan dari penerapan SAP berbasis akrual bertujuan memberikan manfaat lebih bagi para pemangku kepentingan baik para pengguna maupun pemeriksa laporan keuangan pemerintah, dibandingkan dengan biaya yang dikeluarkan.

Laporan keuangan yang dihasilkan dengan basis akrual meliputi laporan realisasi anggaran, neraca, laporan arus kas, laporan operasional, laporan 
perubahan ekuitas, laporan saldo anggaran lebih/kurang, laporan arus kas dan catatan atas laporan keuangan. Entitas akuntansi menyusun laporan realisasi anggaran, neraca, laporan operasional, laporan perubahan ekuitas dan CALK. Dan untuk entitas pelaporan ditambahkan laporan arus kas dan laporan saldo anggaran lebih/ kurang. Perbedaan dengan basis akuntansnsi pada SAP sebelumnya belum mengakui adanya pendapatan-LO dan beban dalam pos-pos laporan keuangan secara akrual atau pada saat terjadinya transaksi. Dalam mempersiapkan penerapan basis akrual dimulai secara bertahap dengan mengukur dan mengakui piutang tak tertagih pada tahun 2012 dan penyusutan pada aset tetap tahun 2014 . Sebelum menghitung penyusutan pada aset tetap terlebih dahulu dilakukan revaluasi aset tetap pada pemerintah pusat dan daerah. Diharapkan hal ini sejalan dengan prinsip akuntansi yaitu bahwa biaya yang dikeluarkan sebanding dengan manfaat yang diperoleh.

\subsection{Permendagri No 64 Tahun 2013}

Dalam hal berkaitan dengan penerapan SAP berbasis akrual sesuai PP No 71 Tahun 2010 maka setiap pemerintah daerah provinsi/ kabupaten dan kota dianggap perlu menyusun kebijakan akuntansi tersebut. Hal ini diatur dalam Peraturan Menteri Dalam Negeri (permendagri) No 64 Tahun 2013 tentang penerapan standar akuntansi pemerintah berbasis akrual pada pemerintah daerah. Dalam permendagri tersebut dilengkapi dengan pedoman penyusunan kebijakan akuntansi pemerintah daerah, panduan penyusunan sistem akuntansi pemerintah daerah, bagan akun standar dan format konversi penyaJIAn laporan realisasi anggaran (LRA).

Kebijakan akuntansi pemerintah daerah merupakan prinsip, dasar dan aturan yang dipilih oleh pemerintah daerah sebagai pedoman dalam menyusun dan menyajikan laporan keuangan pemerintah daerah untuk memenuhi kebutuhan para pengguana laporan keuangan. Masing-masing Kepala daerah berwenang menyusun kebijakan akuntansi yang dapat digunakan sebagai acuan penyusunan laporan keuangan pemerintah daerah berdasarkan SAP No 71 Tahun 2010 yang merujuk pada permendagri No. 64 Tahun 2013.

\subsection{Peraturan Walikota Tangerang Selatan No. 10 Tahun 2014}

Laporan keuangan disusun dengan tujuan untuk memberikan informasi mengenai posisi keuangan, realisasi anggaran, saldo anggaran lebih, arus kas, hasil operasi dan perubahan ekuitas suatu entitas pelaporan yang bermanfaat bagi para pengguna dalam membantu pengambilan keputusan. Untuk wilayah Tangerang Selatan dalam Peraturan walikota No 10 Tahun 2014 tentang kebijakan akuntansi yang berlaku sebagai pedoman dalam penyusunan laporan keuangan yang tetap merujuk pada SAP 71 dan permendagri No.64 Tahun 2013. Ruang lingkup kebijakan akuntansi menjelaskan pengakuan, pengukuran dan pelaporan atas unsur dalam laporan keuangan.

Tujuan dibuatnya kebijakan akuntansi pemerintah daerah untuk dapat menjelaskan adanya akun-akun yang memerlukan pengaturan lebih rinci dalam pengakuan dan pengukurannya. Pihak yang wajib menyusun laporan keuangan pemerintah daerah adalah entitas pelaporan dan entitas akuntansi. Entitas 
pelaporan yaitu SKPKD dan entitas akuntansi yaitu PPKD dan SKPD. Jenis laporan keuangan yang dihasilkan meliputi laporan pelaksanaan anggaran yaitu laporan realisasi anggaran dan laporan saldo anggaran lebih/ kurang, laporan keuangan yaitu laporan posisi keuangan, laporan operasional, laporan arus kas, laporan perubahan ekuitas dan catatan atas laporan keuangan. Untuk laporan saldo anggaran lebih/ kurang dan laporan arus kas tidak disusun oleh entitas akuntansi melainkan disusun oleh SKPKD atau entitas pelaporan selaku yang menyusun laporan konsolidasi pemerintah daerah. Dengan perubahan basis akuntansi yang digunakan secara akrual maka sistem pencatatan akuntansi yang digunakan oleh pemerintah kota Tangerang selatan berubah menjadi sistem informasi manajemen perencanaan, penganggaran dan pelaporan (SIMRAL) pada tahun 2015 dari sebelumnya sistem informasi pengelolaan keuangan daerah (SIAKU). Berubahnya sistem pencatatan ini bertujuan agar perencanaan pembangunan terintegrasi dengan penganggaran dan pengelolaan keuangan daerah, sehingga penggunaan dana APBD untuk membiayai kegiatan dapat dipantau secara langsung oleh pihak eksekutif.

\subsection{Penelitian terdahulu}

a. Penelitian (Yani olga : 2014) penerapan sap 71 tahun 2010 pada SKPD dinas pendapatan dan pengelolaan aset daerah. Hasil penelitian menjelaskan bahwa pengakuan, pengukuran dan penyaJIAn atas pendapatan, belanja dan pembiayaan sesuai dengan SAP.

b. Dalam penelitian (Miftahul jannah : 2015) tentang dampak kebijakan akuntansi pemerintah daerah atas PP No 71 Tahun 2010 dalam rangka pemberian opini laporan keuangan pada dinas pendapatan dan pengelolaan keuangan daerah. Hasil penelitian menjelaskan bahwa SKPD selaku entintas akuntansi belum sepenuhnya menerapkan kebijakan akuntansi melalui laporan keuangan SKPD dan dampak yang ditimbulkan belum maksimal dalam menyusun laporan keuangan berbasis akrual.

c. Penelitian (Paula Ezra : 2016) dengan judul penyaJIAn laporan keuangan daerah sesuai PP No. 71 Tahun 2010 pada dinas pendapatan daerah. Hasil penelitian menunjukkan bahwa SKPD dinas pendapatan daerah belum sepenuhya menerapkan SAP No. 71 Tahun 2010 dilihat dari laporan keuangan yang disusun hanya berupa laporan realisasi anggaran, neraca dan catatan atas laporan keuangan.

\section{METODOLOGI PENELITIAN}

\subsection{Ruang Lingkup Penelitian}

Penelitian ini dilakukan pada Satuan Kerja Perangkat Daerah Kecamatan Ciputat Timur Tangerang Selatan mulai Desember 2017. 


\subsection{Metode Pengumpulan Data}

Jenis data yang digunakan dalam penelitian ini adalah data primer dan data sekunder. Menurut Riadi (2015 : 29), data primer adalah data informasi yang dikumpulkan secara langsung dari sumbernya, yang diperoleh dari tangan pertama melaui pengamatan dan wawancara langsung dengan pihak akuntansi dan pelaporan SKPD Kecamatan Ciputat Timur. Data sekunder adalah informasi yang sudah dikumpulkan oleh beberapa orang (organisasi untuk tujuan tertentu dan tersedia untuk berbagai penelitian yaitu data yang diperoleh melalui dokumen-dokumen atau arsip-arsip entitas akuntansi yang berkaitan dengan penelitian berupa laporan keuangan tahun anggaran 2016 serta catatan-catatan mengenai penerapan basis akrual.

\subsection{Teknik Pengumpulan Data}

\subsubsection{Observasi}

Menurut Sugiyono (2014 : 226) menyatakan bahwa, observasi adalah dasar semua ilmu pengetahuan. Para ilmuan hanya dapat bekerja berdasarkan data, yaitu memperoleh fakta mengenai dunia kenyataan yang diperoleh melalui pengamatan.

\subsubsection{Wawancara}

Menurut Sugiyono (2014 : 231) mendefinisikan wawancara atau interview adalah merupakan pertemuan dua orang untuk bertukar informasi dan ide melalui tanya jawab, sehingga dapat dikonstruksikan makna dalam suatu topik tertentu.

\subsubsection{Dokumentasi}

Dokumentasi merupakan tehnik pengumulan data yang diperlukan berupa dokumen-dokumen yang berhubungan dengan penelitian yag diperoleh mlalui proses permintaan peneliti secaa langsung secara langsung kepada bagan akuntansi (Yani olga : 2014). Studi dokumen merupakan pelengkap dari penggunaan metode observasi dan wawancara dalam penelitian kualitatif.

\subsection{Metode Analisis}

Untuk menjawab rumusan masalah, maka metode analisis yang digunakan adalah metode analisis deskriptif kualitatif dengan tehnik analisis yang digunakan sebagai berikut :

3.4.1 Melakukan pengamatan dan wawancara langsung kepada pihak yang berkepentingan dalam penyusunan lapoan keuangan SKPD tersebut dalam hal ini petugas akuntansi pelaporan dan kasub. Bagian perencanaan dan keuangan.

3.4.2 Dari data yang diperoleh dianalisis secara kualitatif yaitu dengan mengkaji, memaparkan dan menjelaskan untuk mendapatkan gambaran yang menyeluruh tentang penerapan basis akrual yang mengacu SAP No 71 Tahun 2010.

3.4.3 Selanjutnya menganalisis hasil wawancara dan menarik kesimpulan atas kesesuaian penerapan basis akrual pada SKPD Kecamatan Ciputat Timur, langkah berikutnya menganalisis dampak yang diperoleh atas berlakunya 
SAP No 71 Tahun 2010 terhadap informasi yang disajikan dalam laporan keuangan, dengan membandingkan antara sebelum dan setelah penerapan basis akrual pada SKPD Kecamatan Ciputat Timur.

\section{HASIL DAN PEMBAHASAN}

\subsection{Gambaran singkat SKPD Kecamatan Ciputat Timur}

Kecamatan ciputat timur terbentuk berdasarka Peraturan daerah Kabupaten Tangerang Nomor 3 Tahun 2007 tentang pembentukan kecamatan Ciputat Timur, Kecamatan serpong dan kecamatan Setu. Selanjutnya berdasarkan Undang-Undang No 51 Tahun 2008 tentang pembentukan kota Tangerang Selatan di Provinsi Banten maka sejak tanggal 26 November 2008 Kecamatan Ciputat Timur berada dalam wilayah Pemerintah Kota Tangerang Selatan meliputi 6 Kelurahan. Visi Kecamatan ciputat Timur "Terwujudnya Instansi Pemerintahan yang Profesional dalam mewujudkan pembangunan masyarakat yang partisipatif dan berwawasan lingkungan". Dalam struktur organisasi kecamatan ciputat timur dipimpin oleh camat dibantu sekretaris camat, 3 Kasubbag dan 5 Kasi yaitu Kasubbag keuangan, Kasubag umum dan kepegawaian, kasubag program, evaluasi dan pelaporan, Kasi pemerintahan, Kasi kesejahteraan sosial, Kasi pelayanan umum, kasi ekonomi dan pembangunan dan kasi ketentraman dan ketertiban umum.

Sebagai entitas akuntansi kecamatan ciputat timur berkewajiban menyusun dan menyediakan laporan keuangan untuk menyampaikan informasi yang relevan mengenai posisi keuangan dan seluruh transaksi yangn dilakukan SKPD selama satu periode pelaporan. Laporan keuangan yan disusun digunakan untuk membandingkan realisasi pendapatan dan belanja dengan anggaran yang telah ditetapkan, menilai kondisi keuangan, menilai efektivitas da efisiensi kegiatan serta membantu menentukan ketaatan terhadap peraturan perundangan. Selain itu laporan keuangan menyajikan informasi yan bermanfaat bagi para pengguna laporan dalam menilai akuntabilitas dan membuat keputusan baik keputusan ekonomi, sosial maupun politik.

\subsection{Hasil Penelitian}

Dari hasil wawancara dan pengamatan peneliti melakukan analisis untuk melihat kesesuaian laporan keuangan yang disajikan dengan SAP 71, dan juga membandingkan dengan laporan keuangan tahun sebelumnya untuk melihat dampak apa saja yang ditimbulkan.

Tabel 4.1 Hasil Pengamatan dan wawancara

\begin{tabular}{|l|l|l|}
\hline No & $\begin{array}{l}\text { Hasil wawancara } \\
\text { dan pengamatan }\end{array}$ & Uraian \\
\hline 1 & $\begin{array}{l}\text { Persiapan basis } \\
\text { akrual }\end{array}$ & $\begin{array}{l}\text { Diterbitkannya peraturan walikota Tangerang selatan } \\
\text { No. 10 Tahun 2014 tentang kebijakan akuntansi } \\
\text { sebagai acuan penyusunan laporan keuangan bagi } \\
\text { entitas akuntansi dan entitas pelapoan di pemerintah } \\
\text { daerah tangerang selatan }\end{array}$ \\
\hline
\end{tabular}




\begin{tabular}{|l|l|l|}
\hline \multirow{2}{*}{} & & $\begin{array}{l}\text { Perubahan sistem akuntansi yang digunakan dalam } \\
\text { pencatatan akuntansi yaitu sistem informasi } \\
\text { manajemen perencanaan dan pelaporan (SIMRAL) } \\
\text { tahun 2015 dari sebelumnya menggunakan sistem } \\
\text { informasi akuntansi keuangan (SIAKU) }\end{array}$ \\
\hline & $\begin{array}{l}\text { Pendidikan dan pelatihan untuk SDM yang berkaitan } \\
\text { dengan pelaporan dilakukan untuk petugas akuntansi } \\
\text { selaku yang menyusuan laporan keuangan dan aset } \\
\text { tetap yang mengelola barang milik daerah. }\end{array}$ \\
\hline 2 & $\begin{array}{l}\text { Penerapan basis } \\
\text { akrual }\end{array}$ & $\begin{array}{l}\text { Pengakuan pendapatan LO dan beban dalam laporan } \\
\text { operasional }\end{array}$ \\
\hline & $\begin{array}{l}\text { Pengakuan ekuitas dalam neraca yang berasal dari } \\
\text { laporan perubahan ekuitas }\end{array}$ \\
\hline & $\begin{array}{l}\text { Pengakuan surplus/ defisit LO dalam laporan } \\
\text { perubahan ekuitas }\end{array}$ \\
\hline & $\begin{array}{l}\text { Laporan realisasi anggaran menyajikan anggaran } \\
\text { dengan realisasi belanja }\end{array}$ \\
\hline & $\begin{array}{l}\text { Penjelasan pos-pos dan akun-akun dalam laporan } \\
\text { keuangan secara rinci }\end{array}$ \\
\hline
\end{tabular}

Tabel 4.2 Hasil Analisis

\begin{tabular}{|c|c|c|c|}
\hline No & $\begin{array}{c}\text { Basis akrual dalam } \\
\text { penyaJIAn laporan } \\
\text { keuangan }\end{array}$ & $\begin{array}{l}\text { SKPD Kecamatan } \\
\text { Ciputat Timur }\end{array}$ & SAP 71 \\
\hline \multirow[t]{4}{*}{1} & $\begin{array}{l}\text { Laporan } \\
\text { Operasional }\end{array}$ & & \\
\hline & Pendapatan-LO & $\begin{array}{l}\text { Tidak terdapat } \\
\text { pendapatan-LO yang } \\
\text { disajikan dalam laporan } \\
\text { keuangan SKPD baik } \\
\text { pendapatan PAD-LO, } \\
\text { transfer-LO dan } \\
\text { pendapatan lain-lain-LO }\end{array}$ & $\begin{array}{l}\text { Berasal dari } \\
\text { operasional } \\
\text { pendapatan asli daerah- } \\
\text { LO, pendapatan transfer- } \\
\text { LO dan pendapatan lain- } \\
\text { lain-LO berasal dari pajak } \\
\text { dan retribusi, dana alokasi } \\
\text { khusus dan hibah dari } \\
\text { pemerintah kota maupun } \\
\text { provinsi. }\end{array}$ \\
\hline & Beban & $\begin{array}{l}\text { Beban operasi meliputi } \\
\text { beban pegawai, beban } \\
\text { barang dan jasa, dan } \\
\text { beban penyusutan dan } \\
\text { amortisasi }\end{array}$ & $\begin{array}{l}\text { Akun beban diakui pada } \\
\text { saat timbulnya kewajiban, } \\
\text { terjadinya konsumsi aset, } \\
\text { dan penurunan manfaat } \\
\text { ekonomi barang/ jasa. } \\
\text { Beban berasal dari beban } \\
\text { operasi, beban transfer dan } \\
\text { beban lain-lain }\end{array}$ \\
\hline & $\begin{array}{l}\text { Surplus/ } \\
\text { kegiatan }\end{array}$ & $\begin{array}{lrr}\text { Nilai } & \text { diperoleh } & \text { dari } \\
\text { selisih } & & \text { antara }\end{array}$ & $\begin{array}{l}\text { Selisih antara pendapatan- } \\
\text { LO dan beban-LO }\end{array}$ \\
\hline
\end{tabular}




\begin{tabular}{|c|c|c|c|}
\hline & operasional-LO & $\begin{array}{l}\text { pendapatan-LO dan } \\
\text { beban-LO }\end{array}$ & \\
\hline & $\begin{array}{l}\text { Surplus/defisit } \\
\text { kegiatan non } \\
\text { operasional-LO }\end{array}$ & $\begin{array}{ll}\begin{array}{l}\text { Surplus berasal dari } \\
\text { kegiatan }\end{array} & \text { non } \\
\text { operasional lainya-LO }\end{array}$ & $\begin{array}{l}\text { Berasal dari surplus/ } \\
\text { defisit penjualan aset non } \\
\text { lancar dan surplus/ defisit } \\
\text { non operasional lainnya- } \\
\text { LO }\end{array}$ \\
\hline & Surplus/defisit-LO & 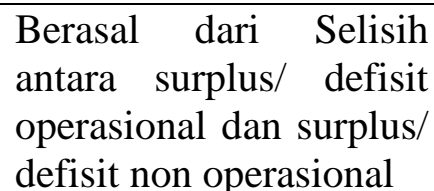 & \begin{tabular}{lcc} 
Selisih antara surplus/ & \multicolumn{2}{c}{ defisit operasional dan } \\
surplus/ defisit & non \\
operasional & &
\end{tabular} \\
\hline \multirow[t]{5}{*}{2} & Neraca & $\begin{array}{l}\text { Posisi keuangan entitas } \\
\text { terdiri dari aset lancar, } \\
\text { aset tetap, aset tak } \\
\text { berwujud dan ekuitas }\end{array}$ & $\begin{array}{l}\text { Menjelaskan posisi } \\
\text { keuangan yang meliputi } \\
\text { aset, kewajiban dan } \\
\text { ekuitas secara lengkap }\end{array}$ \\
\hline & Aset Lancar & $\begin{array}{ll}\text { Aset lancar } & \text { yang } \\
\text { dimiliki entitas } & \text { yaitu } \\
\text { persediaan } & \end{array}$ & $\begin{array}{l}\text { Kas dan setara kas, } \\
\text { piutang, persediaan }\end{array}$ \\
\hline & Aset tetap & $\begin{array}{l}\text { Terdiri dari tanah, } \\
\text { gedung dan bangunan, } \\
\text { peralatan mesin, jalan } \\
\text { irigasi dan akumulasi } \\
\text { penyusutan }\end{array}$ & $\begin{array}{l}\text { Tanah, gedung dan } \\
\text { bangunan, peralatan } \\
\text { mesin, jalan irigasi dan } \\
\text { akumulasi penyusutan }\end{array}$ \\
\hline & Aset tak Berwujud & Software dan amortisasi & $\begin{array}{l}\text { Software, merk dagang, } \\
\text { licensi dan amortisasi }\end{array}$ \\
\hline & ekuitas & $\begin{array}{l}\text { Akun ekuitas di neraca } \\
\text { berasal dari saldo akhir } \\
\text { ekuitas dalam laporan } \\
\text { perubahan ekuitas }\end{array}$ & $\begin{array}{l}\text { Saldo ekuitas di neraca } \\
\text { berasal dari saldo akhir } \\
\text { ekuitas pada laporan } \\
\text { perubahan ekuitas }\end{array}$ \\
\hline \multirow[t]{6}{*}{3} & $\begin{array}{l}\text { Laporan perubahan } \\
\text { ekuitas }\end{array}$ & & \\
\hline & Ekuitas awal & $\begin{array}{l}\text { Berasal dari saldo akhir } \\
\text { ekuitas periode tahun } \\
\text { sebelumnya }\end{array}$ & $\begin{array}{l}\text { Berasal dari saldo akhir } \\
\text { ekuitas periode tahun } \\
\text { sebelumnya }\end{array}$ \\
\hline & Surplus/ defisit-LO & $\begin{array}{lrr}\text { Nilai } & \text { berasal dari } \\
\text { surplus/ } & \text { defisit-Lo } \\
\text { dalam } & \text { laporan } \\
\text { operasional } & \\
\end{array}$ & $\begin{array}{l}\text { Berasal dari nilai surplus/ } \\
\text { defisit-LO dalam laporan } \\
\text { operasional }\end{array}$ \\
\hline & $\begin{array}{l}\text { Saldo anggaran } \\
\text { lebih }\end{array}$ & $\begin{array}{l}\text { Nilai berasal dari neraca } \\
\text { saldo }\end{array}$ & \\
\hline & $\begin{array}{l}\text { Koreksi-koreksi } \\
\text { kesalahan }\end{array}$ & $\begin{array}{l}\text { Nilai yang diperoleh } \\
\text { dari selisih dari ekuitas } \\
\text { awal dengan ekuitas-LO } \\
\text { dalam neraca saldo }\end{array}$ & $\begin{array}{l}\text { Koreksi kesalahan dari } \\
\text { persediaan, nilai revaluasi } \\
\text { aset tetap dan lain-lain }\end{array}$ \\
\hline & Ekuitas akhir & $\begin{array}{l}\text { Nilai yang diperoleh } \\
\text { dari selisih ekuitas awal, }\end{array}$ & $\begin{array}{l}\text { Nilai yang diperoleh dari } \\
\text { selisih ekuitas awal, }\end{array}$ \\
\hline
\end{tabular}




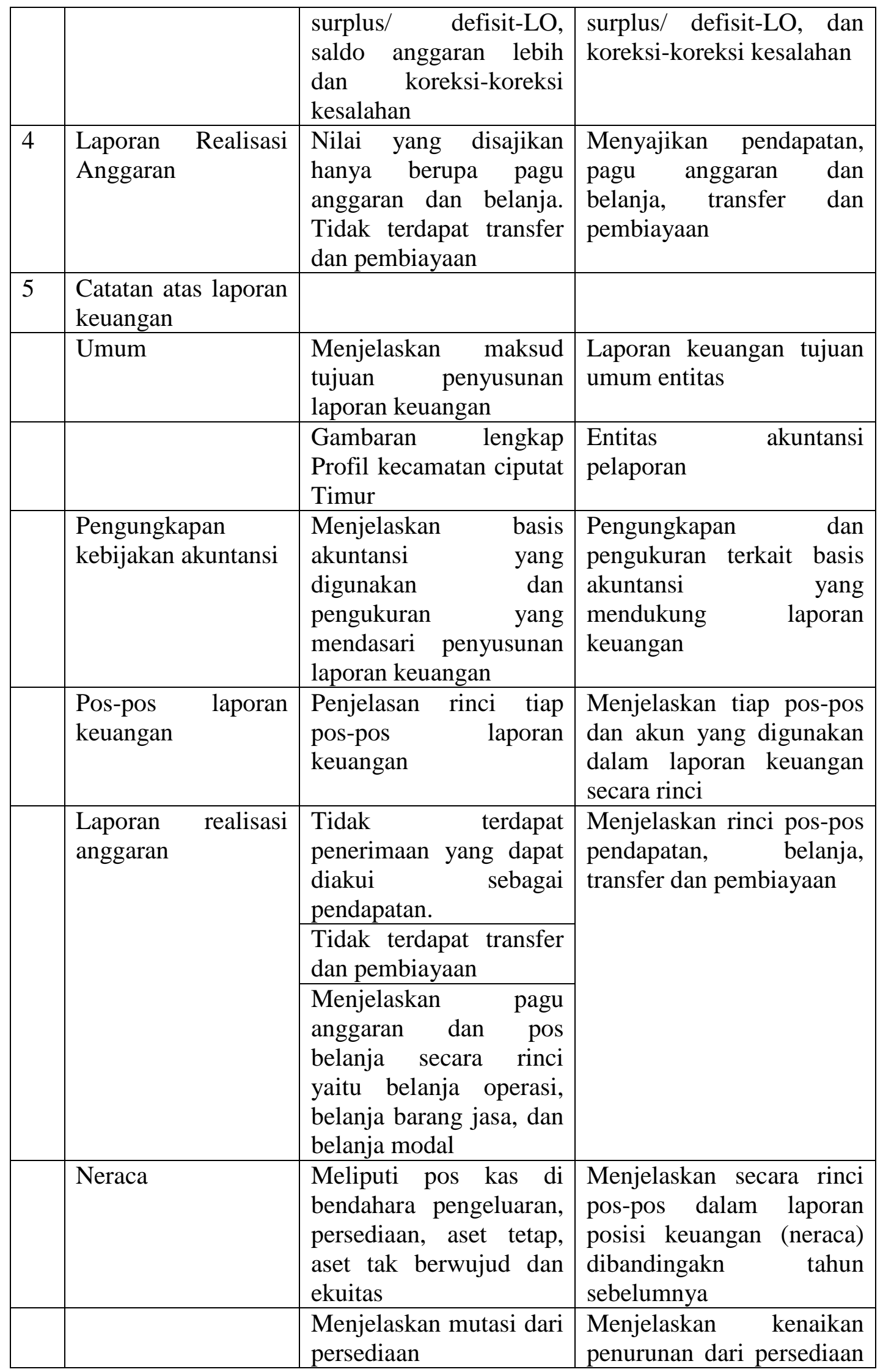




\begin{tabular}{|c|c|c|}
\hline & $\begin{array}{l}\text { dibandingkan tahun } \\
2015\end{array}$ & $\begin{array}{ll}\text { dibandingkan } & \text { tahun } \\
\text { sebelumnya } & \end{array}$ \\
\hline & $\begin{array}{l}\text { Menjelaskan perolehan } \\
\text { tanah, Peralatan mesin, } \\
\text { gedung bangunan dan } \\
\text { jalan dan irigasi, serta } \\
\text { akumulasi penyusutan }\end{array}$ & $\begin{array}{l}\text { Menjelaskan mutasi dari } \\
\text { aset tetap dan akumulasi } \\
\text { penyusutan dibandingkan } \\
\text { tahun sebelumnya }\end{array}$ \\
\hline & $\begin{array}{l}\text { Menjelaskan perolehan } \\
\text { aset tetap lainnya berupa } \\
\text { software SKPD dan } \\
\text { amortisasi }\end{array}$ & $\begin{array}{l}\text { Sesuai SAP } 71 \text { software } \\
\text { termasuk dalam aset tak } \\
\text { berwujud }\end{array}$ \\
\hline & $\begin{array}{l}\text { Menjelaskan mutasi } \\
\text { ekuitas dibandingkan } \\
\text { tahun } 2015\end{array}$ & $\begin{array}{lr}\text { Menjelaskan } & \text { kenaikan } \\
\text { penurunan dari } & \text { ekuitas } \\
\text { dibandingkan } & \text { tahun } \\
\text { sebelumnya } & \end{array}$ \\
\hline $\begin{array}{l}\text { Laporan } \\
\text { Operasional }\end{array}$ & $\begin{array}{lr}\begin{array}{lr}\text { Belum } \\
\text { akun-akun }\end{array} & \begin{array}{r}\text { menjelaskan } \\
\text { dalam }\end{array} \\
\text { laporan } & \text { operasional } \\
\text { pada CALK } & \end{array}$ & $\begin{array}{l}\text { Menjelaskan saldo } \\
\text { pendapatan-LO dan beban, } \\
\text { surplus/ defisit-LO dan } \\
\text { non operasional }\end{array}$ \\
\hline $\begin{array}{l}\text { Laporan perubahan } \\
\text { ekuitas }\end{array}$ & $\begin{array}{lr}\text { Belum } & \text { menjelaskan } \\
\text { akun-akun } & \text { dalam } \\
\text { laporan } & \text { perubahan } \\
\text { ekuitas pada CALK }\end{array}$ & $\begin{array}{l}\text { Menjelaskan lengkap pos- } \\
\text { pos ekuitas awal, surplus/ } \\
\text { defisit, koreksi dan ekuitas } \\
\text { akhir yang diperoleh }\end{array}$ \\
\hline $\begin{array}{l}\text { Pengungkapan } \\
\text { pengungkapan } \\
\text { lainnya }\end{array}$ & & \\
\hline \multirow[t]{2}{*}{$\begin{array}{l}\text { - Temuan dan } \\
\text { tindak lanjut }\end{array}$} & \begin{tabular}{lr}
\multicolumn{2}{l}{ Temuan administratif } \\
yang sifatnya & teguran \\
akan & segera \\
ditindaklanjuti &
\end{tabular} & \multirow[t]{2}{*}{$\begin{array}{l}\text { Mengungkan kejadian- } \\
\text { kejadian penting selama } \\
\text { tahun pelaporan }\end{array}$} \\
\hline & $\begin{array}{lr}\text { Temuan } & \text { berupa } \\
\text { pengembalian uang ke } \\
\text { kas daerah segera } \\
\text { dilakukan penyetoran } \\
\text { melalui Bank Jabar } \\
\text { Banten }\end{array}$ & \\
\hline $\begin{array}{ll} & \text { Rekening } \\
\text { pemerintah }\end{array}$ & $\begin{array}{l}\text { Rekening rinci SKPD } \\
\text { pada Bank Jabar Banten }\end{array}$ & \\
\hline
\end{tabular}

Tabel 4.3 Dampak yang ditimbulkan

\begin{tabular}{|c|c|c|c|c|}
\hline \multirow[t]{2}{*}{ NO } & \multirow[t]{2}{*}{ Uraian } & \multicolumn{2}{|c|}{ Hasil Penerapan Akrual } & \multirow[t]{2}{*}{ Sumber } \\
\hline & & Sebelum 2015 & Setelah 2015 & \\
\hline 1 & $\begin{array}{l}\text { Persiapan } \\
\text { akrual basis }\end{array}$ & $\begin{array}{l}\text { Peraturan walikota } \\
\text { tentang kebijakan } \\
\text { akuntansi basis kas } \\
\text { menuju akrual }\end{array}$ & $\begin{array}{lr}\text { Adanya } & \text { peraturan } \\
\text { walikota } & \text { tentang } \\
\text { kebijakan akuntansi } & \text { pemerintah daerah dan }\end{array}$ & Dokumen \\
\hline
\end{tabular}




\begin{tabular}{|c|c|c|c|c|}
\hline & & & $\begin{array}{l}\text { sistem akuntansi } \\
\text { pemerintah daerah } \\
\text { tentang basis akrual }\end{array}$ & \\
\hline 2 & $\begin{array}{l}\text { Sistem } \\
\text { Akuntansi } \\
\text { Pemerintah }\end{array}$ & $\begin{array}{l}\text { Sistem akuntansi } \\
\text { pemerintah daerah } \\
\text { (SIAKU) } \\
\text { Sistem akuntansi } \\
\text { belum terintegrasi } \\
\text { secara langsung, } \\
\text { sehingga } \\
\text { dimungkinkan } \\
\text { adanya penginputan } \\
\text { belanja modal yang } \\
\text { dilakukan oleh } \\
\text { petugas aset dan } \\
\text { juga petugas } \\
\text { akuntansi pelaporan }\end{array}$ & $\begin{array}{l}\text { Sistem informasi } \\
\text { manajemen } \\
\text { perencanaan dan } \\
\text { pelaporan (SIMRAL) } \\
\text { Sitem akuntansi lebih } \\
\text { terintegrasi sehingga } \\
\text { memudahkan } \\
\text { penginputan belanja } \\
\text { modal oleh petugas } \\
\text { aset dalam menyusun } \\
\text { laporan keuangan yang } \\
\text { secara langsung } \\
\text { diakses (online) oleh } \\
\text { petugas akuntansi } \\
\text { pelaporan }\end{array}$ & Wawancara \\
\hline 3 & $\begin{array}{l}\text { Pengakuan } \\
\text { dan } \\
\text { pengukuran } \\
\text { penyusutan } \\
\text { aset tetap } \\
\end{array}$ & $\begin{array}{l}\text { Belum dilakukan } \\
\text { penyusutan aset } \\
\text { tetap terhadap akun } \\
\text { belanja modal } \\
\text { SKPD }\end{array}$ & $\begin{array}{l}\text { Penyusutan aset tetap } \\
\text { dilakukan terhadap } \\
\text { belanja modal yang } \\
\text { dibeli oleh SKPD } \\
\text { mulai tahun } 2015\end{array}$ & $\begin{array}{l}\text { Wawancara } \\
\text { dan laporan } \\
\text { keuangan }\end{array}$ \\
\hline 4 & $\begin{array}{l}\text { Pengakuan } \\
\text { dan } \\
\text { pengukuran } \\
\text { beban dan } \\
\text { pendapatan- } \\
\text { LO yang } \\
\text { timbul }\end{array}$ & $\begin{array}{l}\text { Belum mengukur } \\
\text { dan mengakui beban } \\
\text { dan pendapatan-LO }\end{array}$ & \begin{tabular}{lr}
\multicolumn{2}{l}{ Mulai disajikan dalam } \\
laporan & $\begin{array}{r}\text { keuangan } \\
\text { laporan }\end{array}$ \\
yaitu & tahun \\
operasional & \\
2015 &
\end{tabular} & $\begin{array}{l}\text { Laporan } \\
\text { keuangan }\end{array}$ \\
\hline 5 & $\begin{array}{l}\text { Perubahan } \\
\text { pengungkapan } \\
\text { dalam CALK }\end{array}$ & $\begin{array}{l}\text { Sesuai SAP basis } \\
\text { kas menuju akrual }\end{array}$ & $\begin{array}{lr}\text { Semua informasi dan } \\
\text { akun-akun } & \text { dalam } \\
\text { laporan } & \text { keuangan } \\
\text { diungkapkan } & \text { secara } \\
\text { memadai } & \text { (full } \\
\text { disclousure) } & \text { sesuai } \\
\text { SAP basis akrual } & \\
\end{array}$ & $\begin{array}{l}\text { Laporan } \\
\text { keuangan }\end{array}$ \\
\hline 6 & $\begin{array}{l}\text { Laporan } \\
\text { keuangan } \\
\text { yang } \\
\text { dihasilkan }\end{array}$ & $\begin{array}{lr}\text { Laporan } & \text { realisasi } \\
\text { anggaran, } & \text { neraca } \\
\text { dan CALK } & \end{array}$ & $\begin{array}{lr}\begin{array}{l}\text { Laporan } \\
\text { anggaran, }\end{array} & \text { realisasi } \\
\text { lapraca, } & \text { operasional, } \\
\text { laporan } & \text { perubahan } \\
\text { ekuitas dan CALK }\end{array}$ & $\begin{array}{l}\text { Laporan } \\
\text { keuangan }\end{array}$ \\
\hline 7 & $\begin{array}{l}\text { Dampak yang } \\
\text { ditimbulkan }\end{array}$ & $\begin{array}{lr}\text { Sistem } & \text { akuntansi } \\
\text { belum } & \text { terintegrasi } \\
\text { secara } & \text { langsung, } \\
\text { sehingga } & \\
\end{array}$ & $\begin{array}{l}\text { Sitem akuntansi lebih } \\
\text { terintegrasi sehingga } \\
\text { memudahkan } \\
\text { penginputan belanja }\end{array}$ & Wawancara \\
\hline
\end{tabular}




\begin{tabular}{|l|l|l|l|}
\hline & $\begin{array}{l}\text { dimungkinkan } \\
\text { adanya penginputan } \\
\text { yang dilakukan oleh } \\
\text { petugas aset dan } \\
\text { juga petugas } \\
\text { akuntansi pelaporan }\end{array}$ & $\begin{array}{l}\text { modal oleh petugas } \\
\text { aset dalam menyusun } \\
\text { laporan keuangan }\end{array}$ & \\
\hline
\end{tabular}

\subsection{Pembahasan}

\subsubsection{Penerapan basis akrual}

Dalam mempersiapkan penerapan basis akrual pemerintah daerah Tangerang Selatan membuat kebijakan akuntansi dengan peraturan Walikota No 10 Tahun 2014 sebagai acuan penyusunan laporan keuangan. Hal ini didukung dengan perubahan sistem akuntansi pemerintah yang digunakan dari SIAKU menjadi SIMRAL pada tahun 2014. SIMRAL merupakan sistem informasi manajemen perencanaan dan pelaporan yang terintegrasi antara perencanaan, penyerapan realisasi belanja dan penyesuaian akun-akun yang dibutuhkan dalam penyusunan laporan keuangan dan ini terus berkembang dengan SIMRAL 2015. Pembekalan pelatihan dipersiapkan untuk sumber daya manusia (SDM) atau pegawai SKPD yang bertugas, sehingga dengan mudah menyesuaikan perubahan sistem akuntansi yang ada. Belanja barang yang bernilai lebih dari Rp. 50.000.000,00 dilakukan pembayaran secara langsung (LS) dan juga untuk semua belanja modal. Pemisahan tugas dan fungsi dilakukan untuk petugas SIAP BMD (barang milik daerah) dan petugas akuntansi pelaporan yang mana terintegrasi secara langsung dalam SIMRAL sehingga tidak perlu dilakukan penginputan ganda. Perubahan jenis laporan keuangan yang dihasilkan oleh SKPD Kecamatan Ciputat Timur sebagai entitas akuntansi dengan menerapkan basis akrual yaitu penambahan penyusunan laporan operasional dan laporan perubahan ekuitas dari yang sebelumnya laporan realisasi anggaran, neraca, dan CALK. Secara rinci analisis perbandingan akan dijelaskan sebagai berikut :

\section{Neraca}

Secara keseluruhan akun-akun dan pos dalam aset, kewajiban dan ekuitas telah dijelaskan dalam CALK sesuai SAP 71. Adanya salah pengungkapan akun yang seharusnya software masuk ke dalam aset tak berwujud tetapi dijelaskan masuk dalam pos aset tetap lainnya.

\section{Laporan operasional}

Laporan yang mengakui adanya pendapatan LO dan beban. Pengukuran pendapatan diakui berdasarkan asas bruto yaitu suatu prinsip yang tidak memperkenankan secara neto penerimaan setelah dikurangi pengeluaran pada suatu entitas organisasi. Pendapatan LO disajikan dalam laporan operasional sesuai klasifikasi BAS dan diungkapkan dalam CALK. Pencatatan beban diakui saat timbul kewajiban untuk membayar, terjadiya konsumsi aset dan adanya penurunan manfaat ekonomis dari suatu barang atau jasa. Beban akumulasi penyusutan dalam metode penyusutan aset tetap yang menggunakan garis lurus. Pencatatan beban disajikan dalam laporan operasional sesuai klasifikasi dalam BAS. Perbandingan antara pendapatan 
LO dan beban menghasilkan surplus/ defisit. Dalamcatatan atas laporan keuangan (CALK) belum dijelaskan secara rinci dan informatif.

\section{Laporan perubahan ekuitas}

Laporan yang menyajikan saldo akhir ekuitas setelah ekuitas awal ditambahkan/ dikurangi surplus/ defisit dalam laporan operasional dan koreksi-koreksi pencatatan belum dijelaskan secara rinci dan informatif dalam catatan atas laporan keuangan (CALK).

4.3.2 Dampak yang terjadi atas penerapan basis akrual dalam penyusunan laporan keuangan meliputi :

1. Penyajian ekuitas akhir diperoleh dari laporan perubahan ekuitas sehingga dapat ditelusur perolehannya.

2. Perhitungan penyusutan dan amortisasi dapat dilakukan pada setiap pembelian untuk aset tetap dan aset tak berwujud dengan melihat harga perolehan dan masa manfaat sesuai kebijakan akuntansi yang berlaku.

3. Dengan adanya perubahan sistem akuntansi pemerintah daerah yaitu SIMRAL maka penyusunan laporan keuangan menjadi lebih mudah, terkoordinasi dan lebih terintegrasi mulai dari penginputan, pencatatan dan pelaporan.

4. Petugas SIAP BMD dan petugas akuntansi pelaporan dapat mengakses SIMRAL tersebut secara online, sehingga waktu pengerjaanya lebih fleksibel dan tidak hanya terbatas dikantor SKPD saja.

5. Dengan adanya penerapan basis akrual yang didukung perubahan sistem akuntansi yang digunakan maka dapat memotivasi sumber daya manusia SKPD yang ada untuk update dan lebih terpacu dalam belajar informasi tehnologi (IT).

6. Sistem akuntansi pemerintah yang ada yaitu sistem informasi manajemen perencanaan, penganggaran dan pelaporan (SIMRAL) dapat digunakan oleh manajemen SKPD sampai dengan Walikota setempat untuk memantau serapan anggaran tiap periode secara langsung (online) dan update, sehingga dapat membantu dalam pengambilan keputusan dan menentukan kebijakankebijakan baru untuk periode selanjutnya.

\section{KESIMPULAN}

\subsection{Kesimpulan}

1. SKPD kecamatan ciputat timur dalam penyusunan laporan keuangan telah menerapkan basis akrual sejak awal tahun 2015 dengan pencatatan menggunakan sistem akuntansi pemerintah yaitu SIMRAL didukungoleh SIAP BMD sesuai dengan SAP 71. Pencatatan akuntansi tersebut dijelaskan dengan penambahan dua laporan keuangan dibandingkan sebelumnya yaitu, adanya pengakuan akun pendapatan LO dan beban dalam laporan operasional, serta akun ekuitas akhir dalam laporan 
perubahan modal. Dalam CALK adanya salah pengungkapan akun yang seharusnya software masuk ke dalam aset tak berwujud tetapi diuraikan dalam pos aset tetap lainnya. Untuk pengungkapan laporan operasional dan laporan perubahan ekuitas belum dijelaskan secara lengkap sesuai SAP 71 dalam catatan atas laporan keuangan (CALK).

2. Dengan penerapan basis akrual pada pencatatan dan penyaJIAn laporan keuangan adanya perubahan yang signifikan terkait sistem akuntansi untuk mendukung penyusunan laporan keuangandan telah memberikan dampak positif. Beberapa dampak yang timbul antara lain adalah PenyaJIAn ekuitas akhir diperoleh dari laporan perubahan ekuitas sehingga dapat ditelusur perolehannya dan perhitungan penyusutan/ amortisasi dapat dilakukan pada setiap pembelian untuk aset tetap dan aset tak berwujud, memudahkan penyusunan laporan keuangan SKPD dengan sistem yang lebih terintegrasi antara petugas akuntansi dan petugas aset BMD, memotivasi SDM untuk mengikuti pelatihan perubahan sistem akuntansi dan mendorong untuk update IT, serta membantu manajemen dalam pengambilan keputusan dengan memantau langsung serapan anggaran melalui SIMRAL.

\subsection{Saran}

1. Untuk peneliti selanjutnya agar mengambil sampel yang lebih luas seperti SKPD pada Dinas ataupun entitas pelaporan yaitu PPKAD.

2. Untuk SKPD kecamatan ciputat timur selanjutnya agar lebih memperhatikan kesesuaian dalam penjelasan terutama untuk akun aset tak berwujud dalam catatan atas laporan keuangan (CALK).

3. Untuk SKPD Kecamatan Ciputat Timur agar menambahkan peyaJIAn dan pengungkapan terutama untuk laporan operasional dan laporan perubahan ekuitas dalam catatan atas laporan keuangan (CALK).

\section{DAFTAR PUSTAKA}

Bastian, Indra. (2014). Audit sektor Publik. Salemba Empat. Jakarta

Ezra, Paula. (2016). Penyajian laporan keuangan daerah sesuai PP Nomor 71 tahun 2010

Hariadi, P; Restianto, Y; \& Bawono, I. (2010) Pengelolaan Keuangan Daerah, Salemba Empa. Jakarta

Jannah, Miftahul. (2015). Dampak kebijakan akuntansi pemerintah daerah atas PP No. 71 Tahun (2010) dalam rangka pemberian opini laporan keuangan.

Olga, Yani. (2014). Penerapan Standar Akuntansi Pemerintah Nomor 71 tahun 2010

Peraturan Pemerintah Indonesia Nomor 71 Tahun (2010) tentang Standar Akuntansi Pemerintah. Jakarta 
Peraturan Pemerintah Indonesia Nomor 8 tahun (2006) tentang pelaporan keuangan dan kinerja Instansi pemerintah.

Peratutan Menteri Dalam Negeri Nomor 64 Tahun (2013) tentang penerapan Standar Akuntansi Pemerintah berbasis akrual pada pemerintah daerah

Peraturan Walikota Tangerang Selatan Nomor 10 Tahun (2014) tentang Kebijakan Akuntansi Pemerintah Daerah Tangerang Selatan

Peraturan Walikota Tangerang Selatan Nomor 24 Tahun (2013) tentang Sistem Akuntansi Pemerinta Daerah Tangerang Selatan

Sugiono. (2014). Metode penelitian kuantitatif, kualitatif dan $R \& D$. Alfabeta. Bandung

Sadeli, Lili M. (2015). Accounting Theory, Edisi 5, Salemba Empat, Jakarta

Sujarweni, V Wiratna. (2015). Akuntansi Sektor Publik. Pustaka Baru Press. Yogyakarta

Tunggal, Wijaya Amin. 2016. Memahami Pengendalian Internal Dalam Audit Laporan Keuangan, Harvarido, Jakarta. 